\title{
The Commission Merchant
}

\section{Livestock commission merchants helped garner higher prices for producers, but the new national livestock trade was also plagued with animal disease and unethical practices.}

\author{
By KC Olson
}

As the size and scale of the Kansas City stockyards increased, it became increasingly difficult for individual ranchers and farmers to market their own animals effectively. Farmers and ranchers lacked market savvy and familiarity with stockyards personnel, which reduced the likelihood of a suitable financial return. This set of circumstances pointed to the need for an intermediary between buyer and seller within the Kansas City stockyards.

The livestock commission merchant appeared to fill this void. Commission merchants arranged the sale of livestock for a consignment fee. They carried out this task not only within the Kansas City stockyards, but often traveled over great distances to locate, solicit, and sell livestock from all over the Southwest. In 1887, 40 livestock commission firms were operating in Kansas City. That number eventually increased to 300 , a figure which remained constant well into the $20^{\text {th }}$ century (Hazlett 1995). The commission merchants operated continuously in the Kansas City stockyards. As such, they were expert observers of price trends and were familiar with the many order buyers and packer buyers who frequented the stockyards. Commission merchants reduced much of the risk associated with marketing livestock in Kansas City by helping livestock owners to choose opportune marketing windows and arranging for the simultaneous sale of multiple classes of livestock.

Surprisingly, they did so at a relatively small cost. The standard con- signment charge was initially $50 \phi$ head for cattle and $10 \phi$ for hogs or sheep. Later, an equivalent charge of \$12/railcar was established for cattle. Similarly, $\$ 6 /$ single-deck railcar or $\$ 10 /$ double-deck railcar was assessed for hogs and sheep (Hazlett 1995). Commission rates for cattle remained constant for 36 years between 1886 and 1921. During that same era, the price of cattle varied from a low of $\$ 3.65 /$ hundredweight in March of 1889 to a high of $\$ 9.60 /$ hundredweight in August of 1912 (Hazlett 1987). The attractive and eminently fair rate scale of the commission merchants soon made selling livestock on consignment the preferred marketing method in the industry.

\section{Commission Merchants Replaced Drovers}

Instead of leveraging $66 \%$ of the value of an animal as a drover might, the commission merchant received $1 \%$ or less. In addition, the commission merchant provided more services than the drover. The commission merchant reduced the costs of marketing and multiplied the classifications and species of animals a producer could market effectively. Historically, the drover only operated in the cattle trade. Railroads enabled the transport not only of cattle but also of sheep and hogs over long distances. Commission merchants happily accepted the task of marketing these livestock species as well.

Nonetheless, cattle dominated the trade receipts in Kansas City. The ratio between cattle, hogs, and sheep in total pounds shipped to Kansas City from 1871 to 1915 was 75:20:5. Huge numbers were involved after the turn of the century. An average of 2.7 million hogs, 2.2 million cattle, and 1.8 million sheep were shipped annually to Kansas City between 1906 and 1915 (Atkinson 1971). Unlike the drover, the commission merchant did not accept ownership of the animals. No one commission merchant could take title to the thousands of animals sent to the market daily; instead they minimized their investment risk by operating on consignment.

A single commission firm owned by A. J. Snider took 19,000 cattle off the grasslands of the Southwest in October 1885 and marketed them in Kansas City. Only a few days elapsed from the time the cattle were loaded onto a railcar to the time the ranchers received payment. In contrast, a drover of that time could trail only 3,000 cattle at once and had to spend a considerable amount of time moving them overland to market. Drovers easily succumbed to this sort of competition from the commission merchants. There was little or no protest from ranchers at the passing of the drover. Producers appreciated the lower costs and greater flexibility granted by the commission merchants during the initial phases of the organizational revolution in the livestock trade.

The ascent of the commission merchant is illustrated in the story of a west Texas cattleman named A. P. Bush. In 1877, Bush spent the entire 
summer in Kansas City and watched the daily telegraph reports from Chicago and St. Louis in an attempt to make the best decision as to when and where to market his cattle. Ironically, Bush used a commission merchant to sell his cattle even though he remained at the market all summer. He became aware that only the commission merchants knew the market well enough to fully exploit its trends (Hazlett 1995).

The early livestock commission merchants of Kansas City further sought ways of distinguishing themselves from their competitor, the drover. The telegraph was one such means. The commission merchants were quick to exploit its value on behalf of their customers. It was the first reliable source of price discovery. For the first time in the history of the animal trade, the telegraph instantly supplied information on price changes in Kansas City, Chicago, St. Louis, and Omaha. Commission merchants kept their customers in the countryside appraised of changing prices with regular market quotes in order to help them pick an advantageous marketing window for their stock. The prepaid telegram was the means by which this information was communicated.

The Texas Live Stock Journal printed on February 9, 1889 recorded the importance of one such prepaid telegram. Several days prior, the cattle market advanced from $15 \phi$ to $25 \phi$ /hundredweight. Simultaneously, several thousand telegrams quoting the price increase were issued from the Kansas City Stockyards. Producers holding cattle on the grasslands west of Kansas City loaded nearly 17,000 animals onto railcars and rushed them to market. As a result, the first to arrive profited from the information. In this way, the telegraph was just as revolutionary to the livestock trade as the railroad.

\section{A Day At The Stockyards}

Daily operations at the stockyards evolved into a highly ordered series of events. Cattle arriving at the stockyards were met by employees of the stockyard company and unloaded

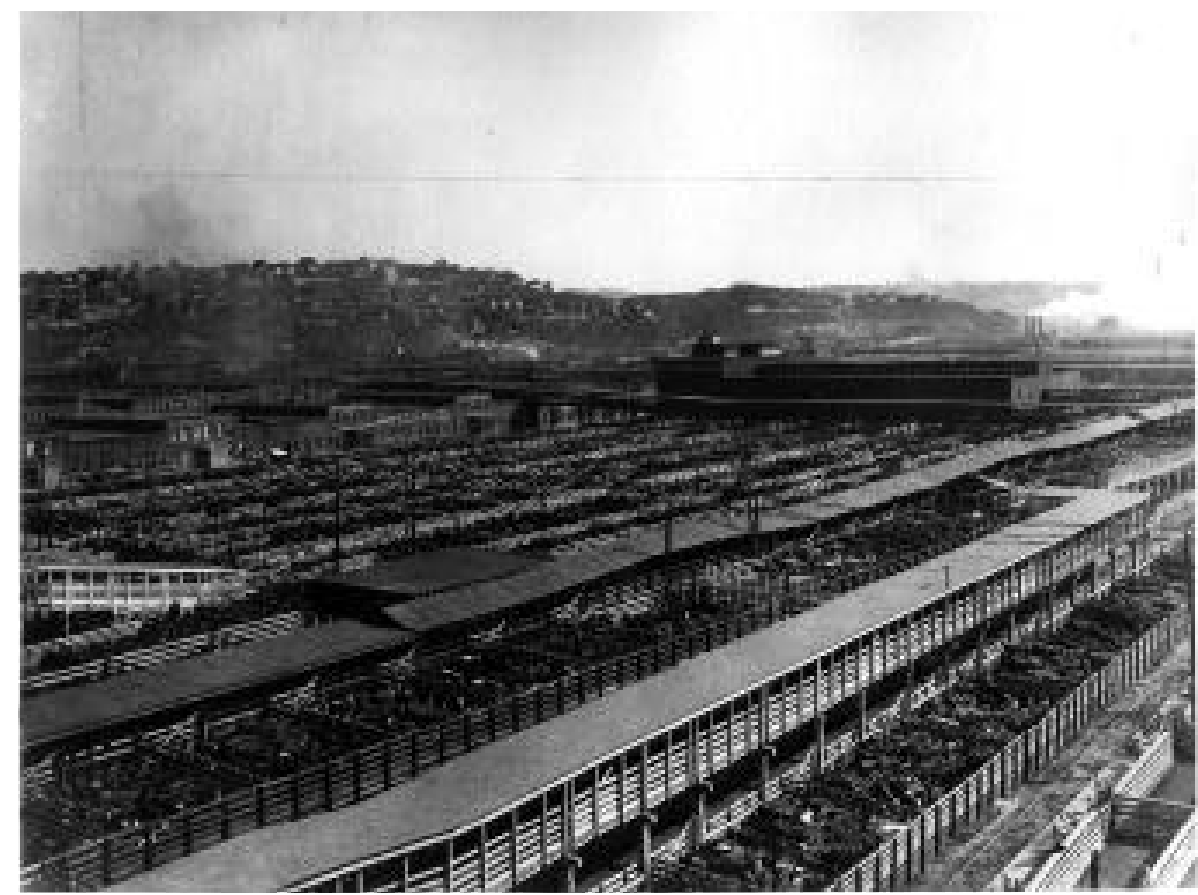

An aerial view of the cattle pens at the Kansas City Stockyards in the early $20^{\text {th }}$ century. Provided by the Kansas State Historical Society - Topeka, Kansas. Reprinted with permission.

from the railcars. Livestock were then delivered to the alleys and pens assigned to the commission firm that was designated by the owner to handle the sale. After that point, employees of the commission firm fed and watered the stock until they were sold. Editions of the Texas Live Stock Journal printed on February $6^{\text {th }}$ and March $13^{\text {th }} 1886$ printed fee scales for the stockyards. Feed charges at the Kansas City stockyards were $\$ 1 /$ bushel of hay and $75 \phi /$ bushel of corn. The yardage charge was $20 \phi /$ head/day for cattle, $8 \phi /$ head/day for hogs, and $5 \notin /$ head/day for sheep. These prices were substantially cheaper than at Chicago: $\$ 1.50 /$ bushel of hay and $\$ 1 /$ bushel of corn; and $25 \phi /$ head/day for cattle, $\$ 8 \not /$ head/day for hogs, and $8 \notin /$ head/day for sheep.

The morning after the livestock arrived, the commission merchant transacted business in the alleys and pens that housed his client's cattle. Packer buyers, order buyers, and cattle feeders rode horses through the alleys or walked along the catwalks constructed over the pens and made their selections. Contracts struck between the commission merchant and the buyers were private treaty affairs and were transacted orally. Many commission men kept the figures in their heads until they returned to the commission office in the exchange building.

Once terms of the sale were agreed upon, the livestock were herded to scales and weighed. There the first record of the transaction occurred when a scale ticket was attached to the bill of lading from the railroad. It was subsequently delivered to the stockyards company office. The buyer was then free to collect his purchase. The commission merchant received payment for the livestock at the stockyards company office. The stockyards company charged the commission firm for the rail freight and the yardage fees. The commission firm then paid the seller after deducting commission, freight, and yardage fees from the total sale price. This process initially took place 24 hours a day, 7 days a week (Hazlett 1995).

A large amount of money changed hands during the course of an average day at the Kansas City Stockyards Company, creating opportunities for 


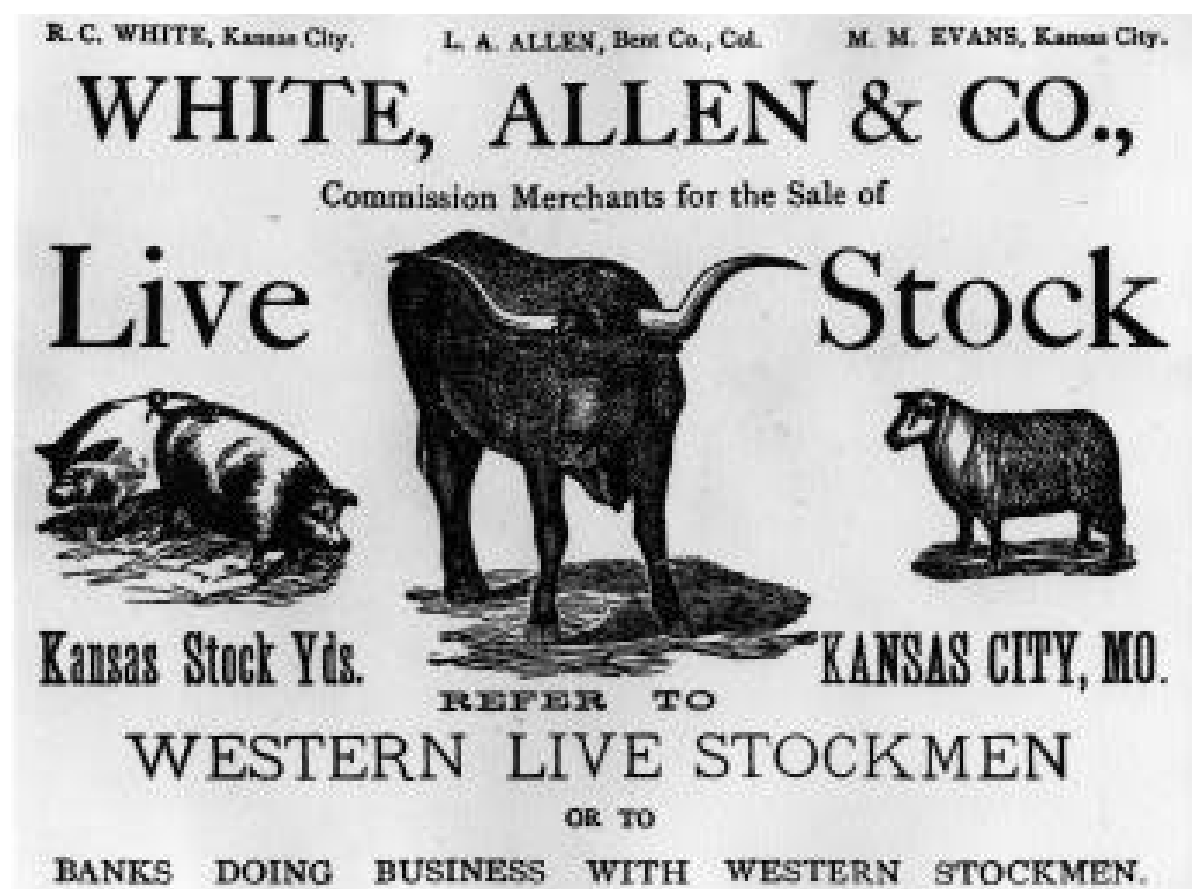

An early handbill advertising the commission services of White, Allen, and Company. Provided by the Kansas State Historical Society - Topeka, Kansas. Reprinted with permission.

both the financier and the cattleman. Kansas City area banks leapt at the opportunity to do business with patrons of the stockyards company. Many opened offices adjacent to the stockyards or within the stockyards building itself to handle the deposits of cattlemen. By the same turn, ranchers had the convenience of borrowing operating capital at the same banks. Kansas City bankers routinely took risks on cattle originating from all over the Southwest.

One such institution was the Emporia National Bank. It loaned $16 \%$ of all operating capital to ranchers in Roberts County Texas in 1900. Overall, Kansas City banks loaned $50 \%$ of the cattle money in the Texas panhandle in that year (Hazlett 1987). In making operating loans to ranchers who lived far from Kansas City, stockyard banks relied heavily on the commission merchant to judge the rancher's character and business acumen. Stockyard banks also depended upon the commission merchant to report on the location and disposition of any cattle under mortgage. In this way, the commission merchant became the critical link between the ranchers in capital poor areas of the West and the Kansas City banks.

Banks were not the only institutions to finance the new cattle trade. The Kansas City livestock commission merchants themselves provided much needed cash flow to ranchers. They often provided financial advances on consigned cattle and they learned quickly that they could direct more business to their firms by giving these advances. Soon it became customary for cattle owners to draw upon commission firms for at least a part of the purchase price of the animals they shipped (Hazlett 1995).

\section{National Markets Lead To National Animal Diseases}

It was inevitable that the freewheeling economic conditions attending the development of the national market in livestock would lead to controversy. Particularly in the frontier areas, local and federal governments were not a regulatory force prior to 1900 . That is, government agencies rarely imposed rules upon industry. It was in this laissez-faire trade environment that unique biological and ethical problems first challenged the national livestock trade.

The biological problem confronting the trade was an unintended consequence of a nation-wide transportation system. As livestock were moved by rail from the four corners of the country to the national markets of the Midwest, they brought with them their endemic diseases. Outbreaks of Texas fever, pleuro-pneumonia, hog cholera, and tuberculosis were only regional in scope prior to the era of rail transport. By 1883 , these diseases became national epidemics and the livestock markets in Kansas City and Chicago became focal points of disease transmission (Hazlett 1992).

The United States government was ill equipped to deal with the crisis. There was no stated policy on the control of animal diseases before 1884 , nor did any federal agency have executive power to deal with such a problem. Livestock producers demanded that the United States Department of Agriculture act during the epidemic outbreaks brought about by rail transport during 1883 . The government responded by creating the Animal Industry Bureau in 1884. This organization was given broad powers to identify and destroy diseased animals. It also had the power to quarantine any stockyards it determined to be infected (Smithcore 1963). The scope of this power directly threatened the livelihood of the livestock commission merchants.

Animal Industry Bureau veterinarians advocated shutting down all stockyards in 1884 when pleuro-pneumonia was diagnosed in Chicago; however, their views inspired little confidence among ranchers and commission merchants. Government veterinarians of the time were not held in high regard (Smithcore 1963). Other prominent veterinarians disputed the claim that pleuro-pneumonia was infectious. In their estimation, the disease could not be contracted in the stockyards. The commission merchants, closely fol- 
lowing the arguments of this faction of experts, acted in their own interest and opposed the closing of the stockyards by the Animal Industry Bureau. This dispute over disease control highlighted the need for the commission merchants to speak with one voice on subjects that affected their business (Hazlett 1992)

In response to the dispute with the Animal Industry Bureau over disease issues, the Chicago livestock commission merchants organized the Chicago Livestock Exchange in March of 1884. As an association, they successfully lobbied the U.S. congress to reduce financial appropriations to the Animal Industry Bureau and to sharply limit its executive powers over the stockyards. In effect, they won the right to regulate stockyards commerce privately, free from government interference (Hazlett 1987). The commission merchants of Kansas City faced similar pressures but resisted organizing as the Chicago merchants had. The Chicago Livestock Exchange had effectively quashed government attempts to regulate the livestock trade over animal disease issues. The need for the Kansas City merchants to form an organization of their own was not urgent from that perspective. The impetus behind development of a livestock exchange there came from a wholly different source; the cattlemen customers of the Kansas City stockyards.

\section{Unethical Behavior Also Plagued Stockyards}

While epidemic livestock diseases threatened the national livestock markets from without, unethical behavior by the commission merchants and packers threatened them from within. The volume and the anonymity common to the newly reorganized livestock trade made the sellers totally dependent on the integrity of their trading partners. That corrupt people would take advantage of what was essentially an honor system was unavoidable. Certain business practices of the commission merchants and the packers were begun in good faith but would later be routinely used to defraud sellers. Naturally, livestock producers were angry and sought justice.

Within the stockyards of Kansas City and Chicago, all contracts between buyers and sellers were oral. The integrity of the commission merchant was the only thing protecting livestock owners from fraud. It was not until the commission merchant rendered the bill of lading and the scale tickets for a given sale at the office of the stockyards company that there was an identifiable contract. It was a relatively easy matter for a dishonest commission merchant to falsify the account of the sale in order to collect a larger consignment fee than was agreed upon.

A Chicago commission merchant, J. S. McFarland, sold 66 heavy cattle for D.P. Taylor of Avoca, Iowa weighing $93,030 \mathrm{lbs}$ for $\$ 4.70$ per hundred. He returned to the seller only $\$ 4.60$ per hundred and pocketed the difference. An audit by the Chicago Livestock Exchange of McFarland's account books uncovered the fraud. He was immediately expelled from the exchange (Hazlett 1987). Kansas City, at the time, had no such mechanism to police its own merchants. Crimes like this, if discovered at all, were instead in the purview of local courts that were notoriously slow to prosecute offenders.

The telegraph was also subject to misuse. Some commission merchants, in an effort to encourage livestock sales during periods of low prices, purposefully misquoted the market in telegraphed price circulars that were widely distributed. The fact that the Kansas City Stockyards initially operated 24 hours per day, seven days per week encouraged this type of behavior. Some merchants conducted their business during the evening hours because fewer people were around the yards to report misdeeds. Adding to the deceit was that livestock shipped in on night trains were often sold before all the buyers appeared in the market during the day. It gave an unfair advantage to some buyers and suppressed competition for the seller's animals.
Unscrupulous livestock buyers were also a problem. Some were known to take advantage of the time lag between the oral contract and the delivery of payment. Deceitful buyers frequently denied agreements made with the commission merchant in the yards when the price of livestock declined during the day. A second problem encountered with livestock buyers was known in the trade as the dockage swindle. Hogs sold by the pound and were subject to a price dock by packer buyers. They docked $40 \mathrm{lbs}$ off the actual weight of a pregnant sow and $80 \mathrm{lbs}$ off of each castrated boar because the pork from these types of animals was viewed as tainted. The weight dock was imposed after the time of sale; the packers quickly learned that the dockage system was a convenient way to reduce the price they paid for hogs. Unfortunately, there was no way a farmer could appeal the dockage decision of the packer buyer (Hazlett 1992).

A hog trader named Z. W. Montague in a letter to Drovers Journal (August 12,1884 ) poignantly illustrated the graft inherent in the dockage system. Montague's commission agent sold his hogs early one morning but the hogs were not weighed and docked until late afternoon. During that day, the price of hogs declined $25 \%$ /hundredweight. Observing this price trend, the packer buyer warned the commission agent that Montague would have to take a big weight dock before payment was rendered. To make his actions less obvious to others in the stockyard, the packer buyer rushed the load of hogs out of the pen six or eight abreast and identified aloud each hog he viewed as imperfect. Montague was astonished at the number of dockages applied by the packer buyer. In his opinion, there was only one dockable hog in the lot but the packer buyer managed to reduce the price of that lot of hogs exactly $25 \phi$ /hundredweight from the high morning price to the low afternoon price (Hazlett 1987).

In principle, both hog traders and packers agreed that there was a legitimate dock for imperfect animals; 
however, it was clear that the packer buyers were using the so-called dockage swindle to control their costs. Volatility was inherent in the hog markets. Prices changed as much as $30 \%$ in one day. Packer buyers could easily lower the price of hogs bought early in the day by applying the dock late in the day. Customers of the stockyards noticed the applied dockage seemed fairer if hog prices went up during the day. It did not take long to figure out why; the buyers were manipulating prices (Hazlett 1987).

Several other business practices of the commission merchants, while inside the letter of the law, were ethically questionable. From the beginning of the commission trade, firms used a type of employee called a solicitor. Solicitors lived at locations remote from stockyards, most often close to a large resource of cattle. They usually held other influential jobs within their local livestock industries. Railroad agents and cattlemen's association representatives were the favored solicitors of the commission firms. Their job was to influence ranchers to consign stock to specific commission houses. In return, solicitors received half the consignment fee. Inside information provided by their solicitors gave a commission house a competitive edge. The fact that blatant conflicts of interest often occurred did not escape the notice of cattlemen. Solicitors became such a controversial part of the business that commission firms rarely identified them publicly. Furthermore, solicitors had little loyalty to any single commission firm; they frequently switched employers for more pay. In time, solicitors brought discredit upon the Kansas City market (Hazlett 1995).

\section{Independent Traders \& Speculators}

Independent livestock traders were common during the late $19^{\text {th }}$ century. Traders stayed in the stockyards at all times and made money principally by taking advantage of market volatility. Traders seldom held stock in their possession more than a few days.
Although not recognized as such, traders in the Kansas City stockyards were the allies of the producer and the enemies of the packer. Without these speculators in the yards, the packers could have exercised an even greater degree of control over the prices of livestock at critical times. Even so, not all speculating was positive.

A second questionable practice of the commission merchants was independent speculation by commission house employees. Employees were free to purchase livestock on their own private accounts in the hopes that prices would rise before resale. Although legal in practice, their speculating was ethically dubious. Commission house employees received discounts on yardage and feed at the Kansas City stockyards. They could afford to hold livestock there over longer periods, while waiting for a market upturn, than could a livestock producer. Inevitably, some poor quality stock came into the possession of commission house employees who traded on their own accounts. Unscrupulous agents could easily substitute their own inferior animals for a customer's high quality animals. The employee was required only to report the number of livestock sold; a few in ferior animals placed in a large load went undetected. Speculating by commission house employees rightfully caused deep resentment among livestock producers (Hazlett 1987).

The third ethical issue encountered at the Kansas City market involved consignment fees. Beginning prior to 1886 , commission firms began to rebate half of the consignment fee for especially large shipments of livestock. This practice became a useful means by which to win customers for a particular commission firm. Unfortunately, it escalated to the point of abuse. Vigorous competition made the commission business difficult to enter because the larger, wealthier firms could operate on narrow financial margins. They could afford to offer continuous commission rebates while the small, newer firms could not.
Four commission firms dominated the cattle trade prior to 1886 . A. J. Snider and Co. marketed $44 \%$ of the cattle sold through the Kansas City stockyards in October of 1885 . Three other firms accounted for $30 \%$ of cattle sold there during that month (Hazlett 1987). In an effort to eliminate competing commission houses, unscrupulous firms also advertised commission rates that were below operating costs. These merchants, in certain instances, made up their losses by falsifying the account of sale and defrauding their customers. Eventually these deeds were discovered (Hazlett 1992).

\section{Cattlemen Form A Voice}

Outcry by the nation's agriculturalists against the poorly handled animal disease epidemics and the unethical business practices of some commission merchants became vehement by 1885. Kansas City commission merchants again felt pressure to organize a regulatory exchange, as the Chicago market had in 1884 , but delayed it for two years. In 1886, powerful cattlemen's associations in the Southwest forced them to act. Organized as early as 1867 (i.e., the Bent County Colorado Cattleman's Association), these private associations organized and controlled their respective local cattle industries. Increasingly intolerant of all middlemen in the trade, they were determined to eliminate them entirely. To this end, the western cattlemen's associations collectively created the International Range Association in January of 1886 . The New Mexico Territorial Cattle Growers Association and the State Livestock Association of Texas organized it. They, in turn, invited cattlemen from other states, Mexico, and British Columbia to join (Hazlett 1987).

Believing that the Animal Industry Bureau would act too late to save western cattle herds from pleuro-pneumonia, the International Range Association established a quarantine of the West against livestock shipped from east of the Missouri river. Moreover, they developed a series of 
executive committees. One timed, adjusted, or regulated the shipments of cattle from different regions in order to prevent a surplus in the markets and to bypass the commission merchants. Another could summarily formulate quarantine regulations. Still another was charged to control stock thieves by prosecuting violators throughout the west. That committee also created a blacklist of cattle industry personnel they viewed as dishonest and forbade members from employing or cooperating with them (Hazlett 1987).

The activities of the International Range Association deeply disturbed the Kansas City livestock merchants. Especially concerning was the threat to bypass the commission firms; the association controlled enough cattle to bring that threat to fruition. The Kansas City merchants were forced to acknowledge that the livestock commission business had numerous problems. If no internal solutions were forthcoming, they felt certain that their critics would succeed in imposing controls from the outside. This was the stimulus that brought about the organization of the Kansas City Livestock Exchange in February 1886 (Hazlett 1992).

Over the course of the next 35 years, the Kansas City Livestock Exchange would become a model of self-regulation in American business. It would effectively police animal disease outbreaks and restore integrity to the livestock trade. Moreover, the exchange also democratized the commission business by giving all firms a voice in the regulatory process and preventing monopolistic business practices by the largest, wealthiest firms.

The International Range Association was not as durable; it only lasted two years. It and other cattle associations lacked effective power. State legislatures were usually unsympathetic and without them the associations could do very little. This fate forced cattlemen to accept the commission merchant's ideas about internal regulation (Hazlett 1987).
The author is an assistant professor, Department of Animal Sciences, University of Missouri - Columbia, Columbia, MO 65211.

To whom correspondence should be addressed

\section{References}

Atkinson, E. L. 1971. Kansas City's livestock trade and packing industry, 1870-1914. Ph.D. Dissertation. University of Kansas, Lawrence.

Hazlett, O. J. 1987. Regulation in the livestock trade: the origins and operations of the Kansas City Livestock Exchange 1886-1921. $\mathrm{Ph}$. D. Dissertation. Oklahoma State University, Stillwater.

Hazlett, O. J. 1992. Chaos and conspiracy: the Kansas City livestock trade. Kansas History 15(2):126-144.

Hazlett, O. J. 1995. Cattle marketing in the American Southwest. Kansas History 18(2):100-115.

Smithcore, J. F. 1963. The American Veterinary Profession: Its Background and Development. Iowa State University Press, Ames, IA.

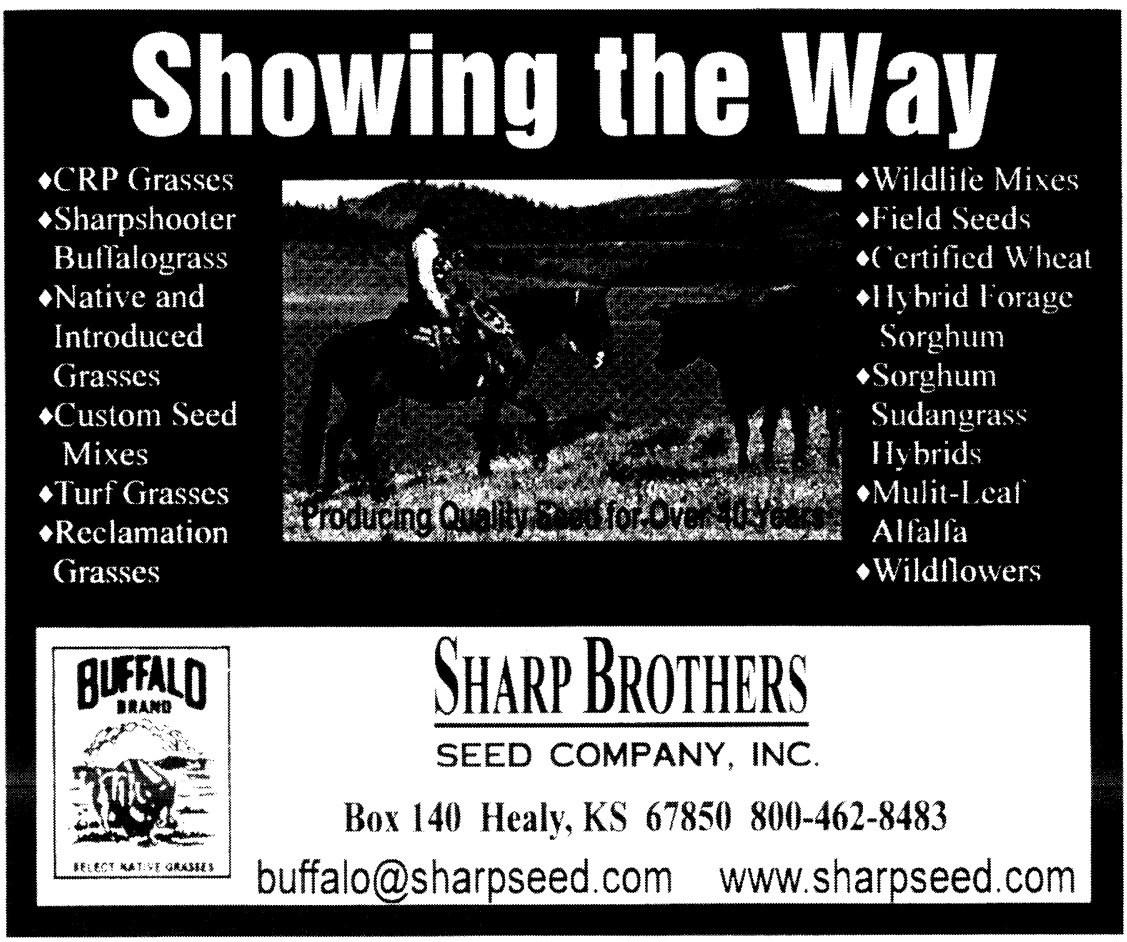

